Please cite this article as: Bailey, A. S. et al. (2022). Identification of Protein-RNA Interactions in Mouse Testis Tissue Using fRIP. Bio-protocol 12(01): e4286. DOI: 10.21769/BioProtoc.4286.

\title{
Identification of Protein-RNA Interactions in Mouse Testis Tissue Using fRIP
}

Alexis S. Bailey ${ }^{1, \#}$, Pedro J. Batista ${ }^{2, \#}$, Howard Y. Chang ${ }^{3}$ and Margaret T. Fuller ${ }^{1, *}$

\author{
1Department of Developmental Biology, Stanford University School of Medicine, Stanford, United States \\ ${ }^{2}$ Laboratory of Cell Biology, Center for Cancer Research, National Cancer Institute (NIH), Bethesda, \\ United States \\ ${ }^{3}$ Center for Personal Dynamic Regulomes, Stanford University School of Medicine, Stanford, United \\ States \\ *For correspondence: mtfuller@stanford.edu \\ \#Contributed equally to this work
}

[Abstract] During development, cells must quickly switch from one cell state to the next to execute precise and timely differentiation. One method to ensure fast transitions in cell states is by controlling gene expression at the post-transcriptional level through action of RNA-binding proteins on mRNAs. The ability to accurately identify the RNA targets of RNA-binding proteins at specific stages is key to understanding the functional role of RNA-binding proteins during development. Here we describe an adapted formaldehyde RNA immunoprecipitation (fRIP) protocol to identify the in vivo RNA targets of a cytoplasmic RNA-binding protein, YTHDC2, from testis, during the first wave of spermatogenesis, at the stage when germ cells are shutting off the proliferative program and initiating terminal differentiation (Bailey et al., 2017). This protocol enables quick and efficient identification of endogenous RNAs bound to an RNA-binding protein, and facilitates the monitoring of stage-specific changes during development. Keywords: fRIP, RNA-binding proteins, Protein-RNA interactions, Post-transcriptional regulation, Immunoprecipitation, RNA targets

[Background] RNA-binding proteins (RBPs) play pivotal roles in controlling gene expression programs during development through both co- and post-transcriptional regulation of RNAs, including splicing, export from the nucleus, mRNA stability, subcellular localization, and translation (Glisovic et al., 2008). During cell differentiation, RNA-binding proteins can help facilitate sharp and accurate cell state transitions by rapidly promoting translation of a new set of RNAs or by degrading RNAs from the previous cell state. RNA-protein interactions can change rapidly during differentiation. Therefore, to uncover the functional role of RBPs in the dynamic state changes that take place in development and tissue restoration or repair, it is critical to be able to efficiently capture RNA-protein interactions as cells within a tissue proceed through the differentiation process.

Several methodologies have been developed to identify RNA-protein interactions, including RNA immunoprecipitation (RIP) and cross-linking immunoprecipitation (CLIP) protocols, which both facilitate identification of RNAs bound to a protein of interest (Ramanathan et al., 2019; Majumder and Palanisamy, 2021). The CLIP method stabilizes RNA-protein complexes through ultraviolet (UV) radiation cross-linking to create an irreversible covalent bond between RNA and protein. However, while 
Please cite this article as: Bailey, A. S. et al. (2022). Identification of Protein-RNA Interactions in Mouse Testis Tissue Using fRIP. Bio-protocol 12(01): e4286. DOI: $10.21769 /$ BioProtoc.4286.

CLIP-seq allows precise detection of RBP-RNA interaction sites, poor UV cross-linking efficiency and adverse effects of UV cross-linking on the ability of an antibody to detect the protein can sometimes prevent sufficient UV cross-linked complexes from being purified using CLIP protocols. As CLIP may not work for all RNA-binding proteins and in all tissue settings, alternative methods to detect endogenous RNA-protein interactions are needed.

The formaldehyde RNA immunoprecipitation (fRIP) method described here, adapted from a protocol developed by the Rinn laboratory, utilizes a light formaldehyde cross-linking step to preserve endogenous RNA-protein interactions and allows efficient RNA and protein recovery that is specific, reproducible, and quantitative (Hendrickson et al., 2016) (Figure 1). The cross-linking step used in the fRIP protocol provides several advantages over previous RIP-seq protocols, by allowing more stringent washes, enhancing protein-RNA specificity, and preventing post-lysis reassociation between proteins and RNA transcripts. Our modified fRIP protocol enabled us to identify both mRNA and long non-coding RNA (IncRNA) targets of the cytoplasmic RNA binding protein YTHDC2 in the mouse testis during the first wave of germ cell development (Bailey et al., 2017). The fRIP protocol is excellent for cell-typespecific analysis in developing tissues, as it requires less material than CLIP methods and the light formaldehyde cross-linking reduces post-lysis contamination from RNAs expressed in other cell types.

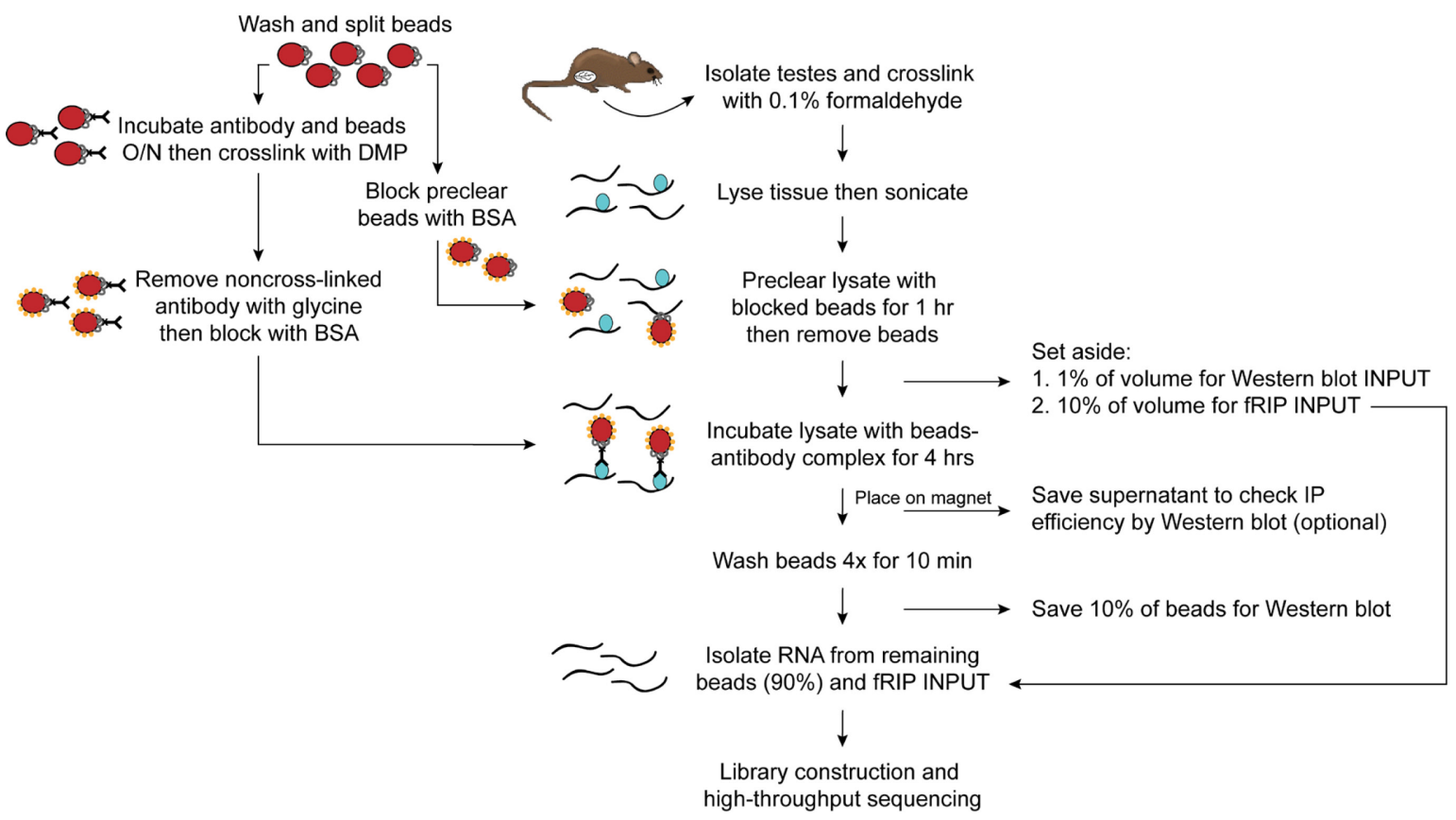

Figure 1. Flowchart of fRIP procedure.

\section{Materials and Reagents}

1. $25 \mathrm{G} \times 5 / 8$ inch needle (Becton Dickinson, catalog number: 305122 )

2. $1 \mathrm{~mL}$ syringe (Becton Dickinson, catalog number: 309659 )

3. $1.7 \mathrm{~mL}$ microcentrifuge tubes (Thomas Scientific, catalog number: $\mathrm{C} 2170$ )

4. Avant $1.7 \mathrm{~mL}$ low binding tubes (Midland Scientific, catalog number: AVSC1510) 
Please cite this article as: Bailey, A. S. et al. (2022). Identification of Protein-RNA Interactions in Mouse Testis Tissue Using fRIP. Bio-protocol 12(01): e4286. DOI: 10.21769/BioProtoc.4286.

5. Mice (wild type and mutant for gene of interest)

6. Formaldehyde, $16 \%$, methanol free, Ultra Pure (Polysciences Inc., catalog number: 18814-10)

7. Glycine (Fisher Scientific, catalog number: BP381-500)

8. Phosphate buffer saline, 10× (PBS) (Gibco, catalog number: 70011044)

9. Dynabeads protein A (Invitrogen, catalog number: 10001D)

10. Ythdc2 antibody, $0.2 \mu \mathrm{g} / \mu \mathrm{L}$ (Bethyl Laboratories, catalog number: A303-025A)

11. Bovine serum albumin (BSA) (Gemini, catalog number: 700-100P)

12. Triethanolamine (Sigma, catalog number: 90279)

13. Dimethyl pimelimidate dihydrochloride (DMP) (Sigma, catalog number: D8388)

14. OmniPur TRIS hydrochloride (Millipore Sigma, catalog number: 9310-OP)

15. Potassium chloride (Fisher Chemical, catalog number: P333-500)

16. Triton X-100 (Sigma, catalog number: T8787)

17. OmniPur glycerol (Millipore Sigma, catalog number: 4750-OP)

18. OmniPur sodium dodecyl sulfate (SDS) (Millipore Sigma, catalog number: 7910-OP)

19. Sodium deoxycholate (Sigma, catalog number: D6750)

20. UltraPure 0.5 M EDTA (Thermo Fisher Scientific, catalog number: 15575020)

21. Sodium chloride (Fisher Chemical, catalog number: S271-500)

22. DTT (Thermo Fisher Scientific, catalog number: P2325)

23. Complete protease inhibitor tablets (CPI) (Roche, catalog number: 05892791001)

24. IGEPAL CA-630 (NP-40) (Sigma, catalog number: I8896)

25. Phenylmethanesulfonyl fluoride (PMSF) (Sigma, catalog number: P7626)

26. RNaseOUT recombinant ribonuclease inhibitor (Invitrogen, catalog number: 10777019)

27. Bradford reagent (Bio-Rad, catalog number: 500-0205)

28. $5 \times$ protein loading buffer (Fermentas, catalog number: R0891)

29. $10 \%$ Mini-PROTEAN TGX precast protein gels, $50 \mu \mathrm{L}$ (Bio-Rad, catalog number: 4561034)

30. Proteinase K (Invitrogen, catalog number: AM2546)

31. TRIzoL (Invitrogen, catalog number: 15596026)

32. Chloroform (Millipore Sigma, catalog number: 3150)

33. GlycoBlue coprecipitant (Invitrogen, catalog number: AM9515)

34. Isopropanol (EMD Millipore, catalog number: PX1835)

35. RiboMinus eukaryote system v2 kit (Ambion, catalog number: A15026)

36. TruSeq RNA sample preparation kit (Illumina, catalog number: FC-122-1001)

37. UltraPure DNase/RNase-free water (Thermo Fisher Scientific, catalog number: 10977015)

38. PBST (see Recipes)

39. $0.1 \%$ formaldehyde (see Recipes)

40. DMP cross-linking solution (see Recipes)

41. Bead coupling buffer (see Recipes)

42. Lysis buffer (see Recipes)

43. Binding/Wash buffer (see Recipes) 
Please cite this article as: Bailey, A. S. et al. (2022). Identification of Protein-RNA Interactions in Mouse Testis Tissue Using fRIP. Bio-protocol 12(01): e4286. DOI: $10.21769 /$ BioProtoc.4286.

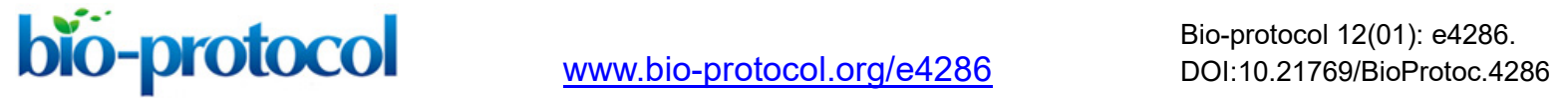

44. Elution buffer (see Recipes)

45. PK buffer (see Recipes)

\section{Equipment}

1. P200 pipette (Rainin, catalog number: 17008652)

2. $-80^{\circ} \mathrm{C}$ freezer (Thermo Scientific)

3. Forceps (Electron Microscopy Sciences, catalog number: 72705-01)

4. Bioruptor for sonication (Diagenode Bioruptor, model: UCD-300)

5. 6-tube magnetic stand (Ambion, catalog number: AM10055)

6. Tube rotator, Labquake Shaker (Lab Industries Inc., catalog number: 400-110)

7. Centrifuge (Eppendorf, model: 5415C)

8. Heat block (VWR Scientific Products)

9. Spectrophotometer (Beckman Coulter, model: DU 640)

\section{Software}

1. Spliced Transcripts Alignment to a Reference (STAR) (Dobin et al., 2013, http://code.google.com/p/rna-star/)

2. HTSeq (Anders et al., 2015, RRID: SCR_005514)

3. DESeq2 (Love et al., 2015, http://www.bioconductor.org/packages/release/bioc/html/DESeq2.html)

\section{Procedure}

A. Cross-linking mouse testes

1. Dissect mouse testes, remove the outer sheath, and carefully tease apart seminiferous tubules using fine forceps (Figure 2). 
A

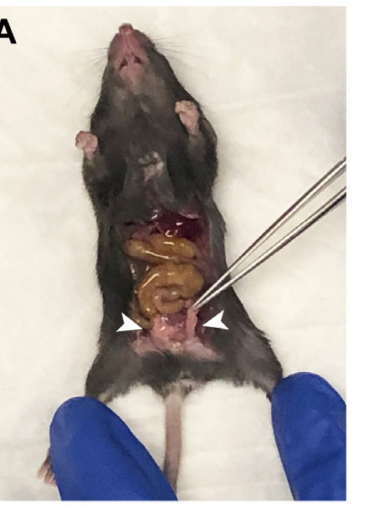

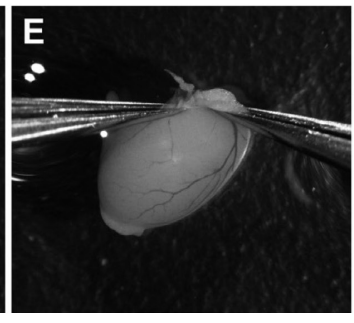

B

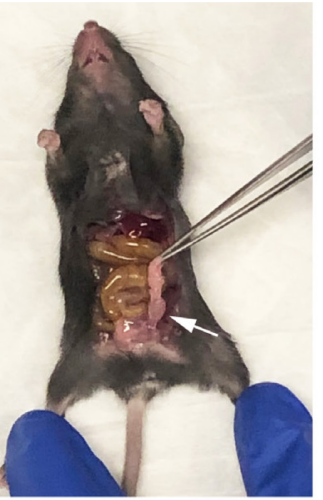

C

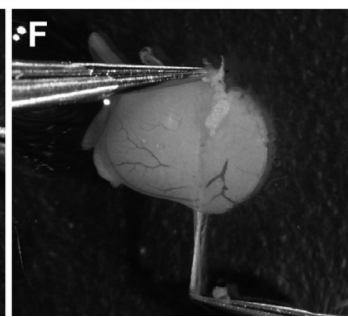

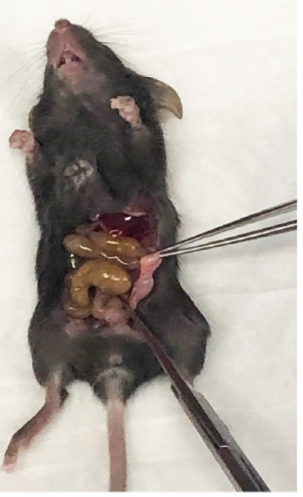

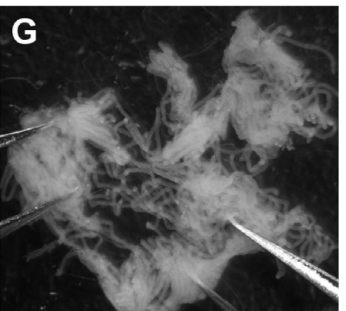

Figure 2. Dissection of mouse testis tubules.

A. After euthanizing the mouse and sanitizing the abdomen with $70 \%$ ethanol, use scissors and forceps to open the abdomen and expose the fat pads in the lower peritoneal cavity (white arrowheads). B. Gently pull on the fat pad until the testis is exposed (white arrow). C. Cut the fat below the testis. D. While working under a microscope, cut the fat and epididymis away from the testis. E. Grab the tunica surrounding the testis with fine forceps. F. Gently pull the tunica away from the testis tubules. G. Carefully tease apart the seminiferous tubules using fine forceps.

2. Place separated seminiferous tubules in a $1.7 \mathrm{~mL}$ microcentrifuge tube and incubate in $0.1 \%$ formaldehyde in PBS at room temperature for 10 min while rotating.

3. Halt cross-linking by adding glycine drop-wise using a P200 pipette to a final concentration of $125 \mathrm{mM}$. Incubate at room temperature for $5 \mathrm{~min}$ while rotating.

4. Pellet the tubules by spinning for $5 \mathrm{~min}$ at $500 \times \mathrm{g}$. Remove the supernatant using a pipette and wash twice with $4^{\circ} \mathrm{C}$ PBS.

5. Re-pellet the tubules, remove the PBS, and flash-freeze in liquid nitrogen. Store at $-80^{\circ} \mathrm{C}$.

B. Cross-linking magnetic Dynabeads to antibody

\section{Day 1}

1. Resuspend the Protein A magnetic Dynabeads by pipetting.

2. Transfer $100 \mu \mathrm{L}$ of Protein A Dynabeads per IP to separate $1.7 \mathrm{~mL}$ microcentrifuge tubes.

3. Place the tubes on the magnet, remove the supernatant, and wash the beads twice with $1 \mathrm{~mL}$ of $3 \%$ BSA in PBST for $5 \mathrm{~min}$ at room temperature while rotating. After each wash, use the magnet to capture the beads, then remove and discard the supernatant.

4. Resuspend the beads in $500 \mu \mathrm{L}$ of $3 \%$ BSA in PBST.

5. Set aside $200 \mu \mathrm{L}$ for the preclear step and store at $4^{\circ} \mathrm{C}$. 
Please cite this article as: Bailey, A. S. et al. (2022). Identification of Protein-RNA Interactions in Mouse Testis Tissue Using fRIP. Bio-protocol 12(01): e4286. DOI: $10.21769 /$ BioProtoc.4286.

6. Place the remaining $300 \mu \mathrm{L}$ on the magnet, remove the supernatant, and resuspend in $200 \mu \mathrm{L}$ of bead coupling buffer.

7. Add $2 \mu \mathrm{g}$ YTHDC2 antibody and incubate at $4^{\circ} \mathrm{C}$ overnight while rotating.

Note: When new antibodies are used, the optimal amount of antibody should be determined by testing the immunoprecipitation efficiency on cross-linked tissue using multiple antibody concentrations (typically between 1-10 $\mu$ g per immunoprecipitation).

\section{Day 2}

8. Place the beads-antibody complex on the magnet and discard the supernatant. Wash three times with $1 \mathrm{~mL}$ of $0.2 \mathrm{M}$ triethanolamine $\mathrm{pH} 8.2$ for $5 \mathrm{~min}$ at room temperature while rotating. After each wash, use the magnet to capture the beads, then remove and discard the supernatant.

9. Resuspend the beads-antibody complex in $1 \mathrm{~mL}$ of dimethyl pimelimidate (DMP) cross-linking solution, and incubate at room temperature for 30 min while rotating.

10. Place the tubes on the magnet to capture the beads, then remove and discard the supernatant.

11. Resuspend the beads-antibody complex in $1 \mathrm{~mL}$ of $50 \mathrm{mM}$ Tris, $\mathrm{pH} 7.5$. Incubate at room temperature for 15 min while rotating.

12. Wash three times with $1 \mathrm{~mL}$ of PBST for $5 \mathrm{~min}$ at room temperature while rotating. After each wash, use the magnet to capture the beads, then remove and discard the supernatant.

13. Resuspend the beads-antibody complex in $200 \mu \mathrm{L}$ of PBST and store at $4^{\circ} \mathrm{C}$.

C. Tissue lysis

1. Remove the testis tubules from the freezer and quickly add $275 \mu \mathrm{L}$ of lysis buffer with $100 \mathrm{U} / \mathrm{mL}$ RNaseOUT to each sample.

Note: We used testis tubules from two postnatal day 12 (P12) mice for each immunoprecipitation.

2. Mechanically break up the testis tubules by pipetting up and down with first a $1,000 \mu \mathrm{L}$ and then a $200 \mu \mathrm{L}$ pipette tip until visibly disrupted. Follow with a $25 \mathrm{G} \times 5 / 8$ inch needle until the lysate can easily pass through the needle (Figure 3 ).
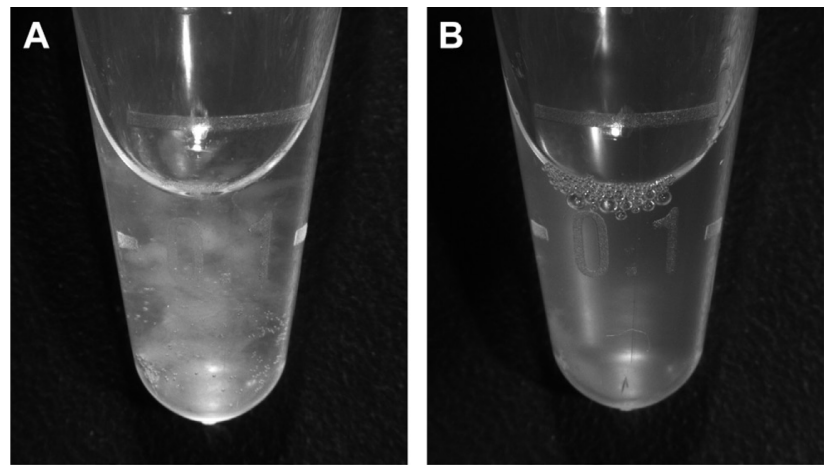

Figure 3. Mechanical disruption of testis tubules.

Cross-linked testis tubules $(A)$ before and $(B)$ after mechanical disruption in lysis buffer. 
Please cite this article as: Bailey, A. S. et al. (2022). Identification of Protein-RNA Interactions in Mouse Testis Tissue Using fRIP. Bio-protocol 12(01): e4286. DOI: $10.21769 /$ BioProtoc.4286.

3. Incubate the lysate at $4^{\circ} \mathrm{C}$ for $15 \mathrm{~min}$ while rotating.

4. Sonicate the lysate in a $4^{\circ} \mathrm{C}$ water bath using a Bioruptor ( $1 \mathrm{cycle}, 30 \mathrm{~s}$ pulse on Medium). Note: May need to test multiple sonication cycle numbers prior to fRIP. The 1 cycle sonication step used in this experiment was gentle enough to not degrade the RNA and protein while lightly fragmenting the RNA. Should be able to easily pipette the lysate following sonication.

5. Spin down debris at $16,000 \times g$ for $15 \mathrm{~min}$ at $4^{\circ} \mathrm{C}$.

6. Collect the supernatant and transfer it to a new $1.7 \mathrm{~mL}$ microcentrifuge tube, then dilute by adding an equal volume of binding/wash buffer with $100 \mathrm{U} / \mathrm{mL}$ RNaseOUT.

7. Calculate protein concentration using the Bradford assay.

Note: We typically obtain around 1.5-2 mg total protein from each lysate (testis tubules from two P12 mice).

8. Use between 1-2 $\mathrm{mg}$ total protein per IP.

D. Preclear lysate

1. Place the beads previously set aside in section $B$ for the preclear step on the magnet and remove the supernatant. Wash the beads twice with $1 \mathrm{~mL}$ of $3 \% \mathrm{BSA}$ in PBST for $15 \mathrm{~min}$ at $4^{\circ} \mathrm{C}$ while rotating. Use the magnet to capture the beads, then remove and discard the supernatant.

2. For each IP, add $\sim 1 \mathrm{mg}$ of total protein to the preclear beads and incubate the lysate for $1 \mathrm{~h}$ at $4^{\circ} \mathrm{C}$ while rotating.

3. Use the magnet to capture the preclear beads, then collect the lysate and transfer it to a new $1.7 \mathrm{~mL}$ microcentrifuge tube. Keep the precleared lysate at $4^{\circ} \mathrm{C}$.

4. Set aside $1 \%$ of the volume of the precleared lysate for western blot analysis. Add protein loading buffer, boil for $5 \mathrm{~min}$ at $100^{\circ} \mathrm{C}$, and freeze.

5. Set aside $10 \%$ of the volume of the precleared lysate for fRIP INPUT. Keep the fRIP INPUT at $4^{\circ} \mathrm{C}$.

E. Beads-antibody preparation

1. To remove any non cross-linked antibody, place the cross-linked beads-antibody complex from section $B$ on the magnet, discard the supernatant, then quickly resuspend the beads in $1 \mathrm{~mL}$ of $100 \mathrm{mM}$ glycine $\mathrm{pH} 2.5$ by inverting the tube. Immediately place the beads back on the magnet, discard the supernatant, and repeat the glycine wash.

2. Wash the beads-antibody complex three times with $1 \mathrm{~mL}$ of PBST for $5 \mathrm{~min}$ at room temperature while rotating. After each wash, use the magnet to capture the beads, then remove and discard the supernatant.

3. Resuspend the beads-antibody complex in $1 \mathrm{~mL}$ of $3 \%$ BSA in PBST and incubate for $30 \mathrm{~min}$ at $4^{\circ} \mathrm{C}$ while rotating.

4. Wash the beads-antibody complex three times quickly in $1 \mathrm{~mL}$ of PBST at room temperature. After each resuspension in PBST, use the magnet to capture the beads, then remove and discard the supernatant. 
Please cite this article as: Bailey, A. S. et al. (2022). Identification of Protein-RNA Interactions in Mouse Testis Tissue Using fRIP. Bio-protocol 12(01): e4286. DOI: $10.21769 /$ BioProtoc.4286

5. Resuspend the beads-antibody complex in PBST and transfer to $1.7 \mathrm{~mL}$ low binding tubes for immunoprecipitation.

F. Immunoprecipitation (IP)

1. Place the beads-antibody complex from section $E$ on the magnet, discard the supernatant, and add the precleared lysate from section $D$.

2. Incubate for $4 \mathrm{~h}$ at $4^{\circ} \mathrm{C}$ while rotating.

3. Capture the beads with bound protein of interest using the magnet, collect the supernatant, and store at $-80^{\circ} \mathrm{C}$ to check IP efficiency by western blot (optional). Keep the beads for the next step.

4. Wash the beads four times with $1 \mathrm{~mL}$ of binding/wash buffer, rotating at $4^{\circ} \mathrm{C}$ for $10 \mathrm{~min}$ each time. After each wash, use the magnet to capture the beads, then remove and discard the supernatant. Transfer the suspended beads to new $1.7 \mathrm{~mL}$ low binding tubes before the final wash.

5. After the final wash, resuspend the beads in $1 \mathrm{~mL}$ of binding/wash buffer and transfer to new $1.7 \mathrm{~mL}$ low binding tubes.

6. Save $10 \%$ of each bead suspension for western blot to confirm successful IP and use $90 \%$ for RNA isolation.

7. For western blot samples ( $10 \%$ of each IP) (Figure 4$)$ :

a. Capture the beads using the magnet and remove the supernatant. Resuspend the beads in $100 \mu \mathrm{L}$ of lysis buffer and transfer to new $1.7 \mathrm{~mL}$ low binding tubes.

b. Place the beads on the magnet and remove the supernatant. Add $40 \mu \mathrm{L}$ of fresh elution buffer to the beads and incubate on a heat block at $70^{\circ} \mathrm{C}$ for $30 \mathrm{~min}$. Briefly vortex the samples every 5 min during the elution step.

c. Spin the tubes at room temperature for $10 \mathrm{~s}$ at $16,000 \times g$.

d. Capture the beads using the magnet and transfer the $40 \mu \mathrm{L}$ of supernatant to new tubes. Add $10 \mu \mathrm{L}$ of $5 \times$ protein loading buffer, boil $5 \mathrm{~min}$ at $100^{\circ} \mathrm{C}$, and freeze.

e. Run samples on a Mini-PROTEAN precast gel.

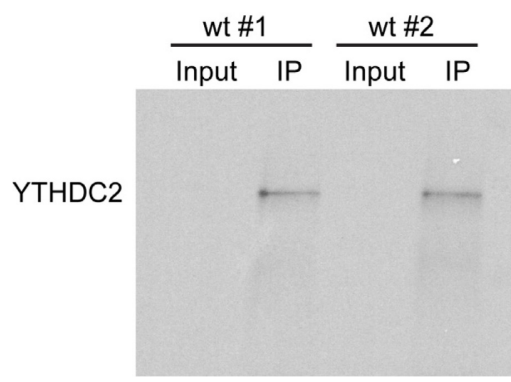

Figure 4. Western blot to confirm success of immunoprecipitation.

Input and $10 \%$ of the immunoprecipitation (IP) samples from wild type (wt) were separated by polyacrylamide gel electrophoresis (PAGE) then transferred to a polyvinylidene difluoride (PVDF) membrane for analysis by western blot. IPs were performed in duplicate. The blot was probed with anti-YTHDC2 antibody. 
Please cite this article as: Bailey, A. S. et al. (2022). Identification of Protein-RNA Interactions in Mouse Testis Tissue Using fRIP. Bio-protocol 12(01): e4286. DOI: 10.21769/BioProtoc.4286.

Note: Proceed with the RNA release step immediately following the immunoprecipitation.

G. Release of RNA

\section{Day 1}

1. Place the $90 \%$ of beads set aside for RNA isolation in step F6 on the magnet and remove the supernatant. Resuspend the beads in $93 \mu \mathrm{L}$ of PK buffer, then add $5 \mu \mathrm{L}$ of $20 \mathrm{mg} / \mathrm{mL}$ Proteinase $\mathrm{K}, 1 \mu \mathrm{L}$ of $40 \mathrm{U} / \mu \mathrm{L}$ RNaseOUT, and $1.5 \mu \mathrm{L}$ of $1 \mathrm{M} \mathrm{DTT}$ (100 $\mu \mathrm{L}$ total volume).

2. To the fRIP INPUT samples from step D5, add $43 \mu \mathrm{L}$ of PK buffer, followed by $5 \mu \mathrm{L}$ of $20 \mathrm{mg} / \mathrm{mL}$ Proteinase $\mathrm{K}, 1 \mu \mathrm{L}$ of $40 \mathrm{U} / \mu \mathrm{L}$ RNaseOUT, and $1.5 \mu \mathrm{L}$ of $1 \mathrm{M} \mathrm{DTT}$ (100 $\mu \mathrm{L}$ total volume).

3. Incubate samples for $1 \mathrm{~h}$ at $42^{\circ} \mathrm{C}$, then another hour at $55^{\circ} \mathrm{C}$.

4. Add $1 \mathrm{~mL}$ of TRIzol, mix by inversion, and let sit $\sim 5 \mathrm{~min}$ at room temperature.

5. Add $200 \mu \mathrm{L}$ of chloroform and shake vigorously for $15 \mathrm{~s}$.

6. Centrifuge $20 \mathrm{~min}$ at $4^{\circ} \mathrm{C}$ at $16,000 \times g$.

7. Collect aqueous layer and add $1 \mu \mathrm{L}$ of GlycoBlue, and $750 \mu \mathrm{L}$ of isopropanol.

8. Incubate overnight at $-20^{\circ} \mathrm{C}$.

\section{Day 2}

9. To isolate the RNA pellet, centrifuge $40 \mathrm{~min}$ at $4^{\circ} \mathrm{C}$ at $16,000 \times \mathrm{g}$.

10. Wash the RNA pellet three times with fresh $75 \%$ cold ethanol, spinning $15 \mathrm{~min}$ at $\sim 7,000 \times g$ between washes.

11. Spin an extra 5 min at $\sim 7,000 \times g$ and air-dry pellet.

12. Resuspend pellet in $10 \mu \mathrm{L}$ of UltraPure DNase/RNase-free water.

H. Library construction

1. Remove ribosomal RNA from both the INPUT and fRIP samples using the RiboMinus Eukaryote System v2 Kit, according to the manufacturer's instructions.

2. Prepare libraries using a TruSeq RNA Sample Preparation Kit per the manufacturer's instructions, with the following modification: do not fragment the RNA with FPF solution.

I. High-throughput sequencing

Sequence libraries using the Illumina NextSeq for $2 \times 75$ bp cycle run.

Note: All work must be performed in an RNase-free environment throughout the fRIP-seq protocol. Only RNase-free solutions should be used.

\section{Data analysis}

Analyze data as described in the Methods section of Bailey et al. (2017). Briefly, filter reads for all samples for quality score and map to rRNA to remove rRNA reads. Map the remaining reads to the 
Please cite this article as: Bailey, A. S. et al. (2022). Identification of Protein-RNA Interactions in Mouse Testis Tissue Using fRIP. Bio-protocol 12(01): e4286. DOI: $10.21769 /$ BioProtoc.4286.

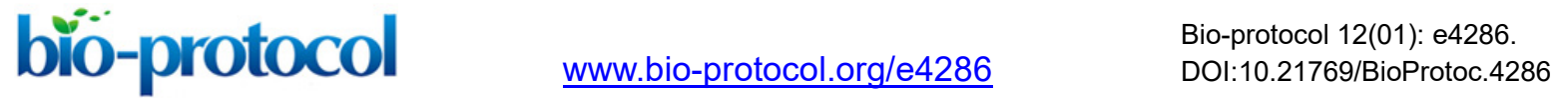

appropriate genome assembly using STAR. Extract reads mapping to each transcript with HTseq, using a custom annotation that includes piRNA precursors, in addition to coding and long-noncoding transcripts. Determine transcripts enriched by IP with DESeq2 using multifactor analysis. Inclusion of the null mutant samples allows for the identification of non-specific interactions.

\section{$\underline{\text { Recipes }}$}

1. PBST

PBS $+0.1 \%$ Tween-20 diluted from $20 \%$ stock solution .

Store at room temperature.

2. $0.1 \%$ formaldehyde

$5 \mathrm{~mL}$ of PBS $+31.25 \mu \mathrm{L}$ of $16 \%$ formaldehyde stock solution.

Make fresh and use immediately.

3. DMP cross-linking solution

$5.4 \mathrm{mg}$ dimethyl pimelimidate (DMP) in $1 \mathrm{~mL}$ of $0.2 \mathrm{M}$ triethanolamine $\mathrm{pH}$ 8.2.

Make fresh and use immediately.

4. Bead Coupling Buffer

Stock Reagent

$1 \mathrm{M}$ Tris- $\mathrm{HCl} \mathrm{pH} 8$

$5 \mathrm{M} \mathrm{NaCl}$

Glycerol

$10 \%$ NP-40

0.5 M EDTA

UltraPure DNase/RNase-free water

5. Lysis Buffer

Stock Reagent

$1 \mathrm{M}$ Tris- $\mathrm{HCl} \mathrm{pH} 8$

$2 \mathrm{M} \mathrm{KCl}$

$10 \%$ SDS

$10 \%$ Triton X-100

$0.5 \mathrm{M}$ EDTA

10\% Sodium Deoxycholate

$1 \mathrm{M} \mathrm{DTT}$

Complete Protease Inhibitor (CPI) $7 \times$

UltraPure DNase/RNase-free water

${ }^{* *}$ Add 100 Units/mL RNaseOUT fresh.

$\begin{array}{ll}\text { Amount for } \mathbf{1 ~ m L} & \text { Final concentration } \\ 20 \mu \mathrm{L} & 20 \mathrm{mM} \\ 27 \mu \mathrm{L} & 135 \mathrm{mM} \\ 100 \mu \mathrm{L} & 10 \% \\ 100 \mu \mathrm{L} & 10 \% \\ 20 \mu \mathrm{L} & 5 \mathrm{mM} \\ 733 \mu \mathrm{L} & \mathrm{n} / \mathrm{a}\end{array}$

\section{Amount for $1 \mathrm{~mL}$ Final concentration}

$50 \mu \mathrm{L}$

$50 \mathrm{mM}$

$75 \mu \mathrm{L}$

$150 \mathrm{mM}$

$10 \mu \mathrm{L}$

$0.1 \%$

$100 \mu \mathrm{L}$

$1 \%$

$10 \mu \mathrm{L}$

$5 \mathrm{mM}$

$50 \mu \mathrm{L}$

$0.5 \%$

$0.5 \mu \mathrm{L}$

$0.5 \mathrm{mM}$

$150 \mu \mathrm{L}$

$1 \times$

$555 \mu \mathrm{L}$

$\mathrm{n} / \mathrm{a}$

6. Binding/Wash Buffer

\section{Stock Reagent}

$1 \mathrm{M}$ Tris- $\mathrm{HCl} \mathrm{pH} 7.5$

\section{Amount for $1 \mathrm{~mL}$ Final concentration}

$25 \mu \mathrm{L}$
$25 \mathrm{mM}$ 
Please cite this article as: Bailey, A. S. et al. (2022). Identification of Protein-RNA Interactions in Mouse Testis Tissue Using fRIP. Bio-protocol 12(01): e4286. DOI: $10.21769 /$ BioProtoc.4286.

$\begin{array}{lll}2 \text { M KCL } & 75 \mu \mathrm{L} & 150 \mathrm{mM} \\ 0.5 \text { M EDTA } & 10 \mu \mathrm{L} & 5 \mathrm{mM} \\ 10 \% \text { NP-40 } & 50 \mu \mathrm{L} & 0.5 \% \\ 1 \mathrm{M} \text { DTT } & 0.5 \mu \mathrm{L} & 0.5 \mathrm{mM} \\ \text { Complete Protease Inhibitor (CPI) } 7 \times & 150 \mu \mathrm{L} & 1 \times \\ \text { UltraPure DNase/RNase-free water } & 690 \mu \mathrm{L} & \mathrm{n} / \mathrm{a}\end{array}$

**Add 100 Units/mL RNaseOUT fresh.

7. Elution Buffer

\section{Stock Reagent}

$10 \%$ SDS

0.5 M EDTA

$1 \mathrm{M}$ Tris-HCL, pH 8.0

100 mM PMSF

Complete Protease Inhibitor (CPI) 7×

UltraPure DNase/RNase-free water

8. PK Buffer

\section{Stock reagent}

$1 \mathrm{M}$ Tris $\mathrm{pH} 7.0$

$5 \mathrm{M} \mathrm{NaCl}$

$0.5 \mathrm{M}$ EDTA

$10 \%$ SDS

UltraPure DNase/RNase-free water

$\begin{array}{ll}\text { Amount for } \mathbf{~ m L} & \text { Final con } \\ 100 \mu \mathrm{L} & 1 \% \\ 20 \mu \mathrm{L} & 10 \mathrm{mM} \\ 50 \mu \mathrm{L} & 50 \mathrm{mM} \\ 10 \mu \mathrm{L} & 1 \mathrm{mM} \\ 150 \mu \mathrm{L} & 1 \times \\ 670 \mu \mathrm{L} & \mathrm{n} / \mathrm{a}\end{array}$

Amount for $25 \mathrm{~mL}$ Final concentration

$250 \mu \mathrm{L}$

$10 \mathrm{mM}$

$500 \mu \mathrm{L}$

$100 \mathrm{mM}$

$50 \mu \mathrm{L}$

$1 \mathrm{mM}$

$1,250 \mu \mathrm{L}$

$0.5 \%$

$22,950 \mu \mathrm{L}$

\section{Acknowledgments}

This protocol was adapted from Hendrickson et al. (2016). We thank the Stanford Functional Genomics Facility for high-throughput sequencing. This work was supported by the National Institutes of Health (NIH T32 AR007422) to A.S.B., the National Cancer Institute, Intramural Research Program of the NIH to P.J.B., the National Institutes of Health (NIH R01 HG004361) to H.Y.C., and the National Institutes of Health (R01 GM122951 and R35 GM136433) and the ReedHodgson Professorship in Human Biology to M.T.F. This adapted protocol was originally published in our previous manuscript (Bailey et al., 2017; Doi: 10.7554/eLife.26116).

\section{Competing interests}

The authors declare no competing interests.

\section{Ethics}


Please cite this article as: Bailey, A. S. et al. (2022). Identification of Protein-RNA Interactions in Mouse Testis Tissue Using fRIP. Bio-protocol 12(01): e4286. DOI: $10.21769 /$ BioProtoc.4286.

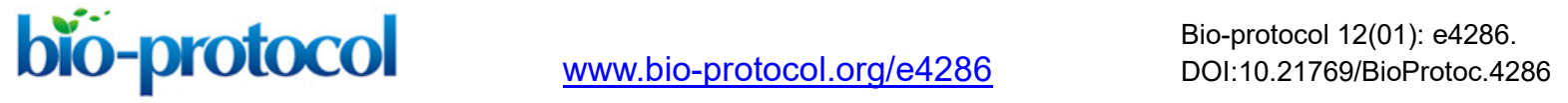

The experiment was approved by the Stanford University Animal Care and Use Committee (IACUC), protocol (\#21656).

\section{References}

1. Anders, S., Pyl, P. T. and Huber, W. (2015). HTSeq--a Python framework to work with highthroughput sequencing data. Bioinformatics 31(2): 166-169.

2. Bailey, A. S., Batista, P. J., Gold, R. S., Chen, Y. G., de Rooij, D. G., Chang, H. Y. and Fuller, M. T. (2017). The conserved RNA helicase YTHDC2 regulates the transition from proliferation to differentiation in the germline. Elife 6: e26116

3. Dobin, A., Davis, C. A., Schlesinger, F., Drenkow, J., Zaleski, C., Jha, S., Batut, P., Chaisson, M. and Gingeras, T. R. (2013). STAR: ultrafast universal RNA-seq aligner. Bioinformatics 29(1): 15-21.

4. Glisovic, T., Bachorik, J. L., Yong, J. and Dreyfuss, G. (2008). RNA-binding proteins and posttranscriptional gene regulation. FEBS Lett 582(14): 1977-1986.

5. Hendrickson, D. G., Kelley, D. R., Tenen, D., Bernstein, B. and Rinn, J. L. (2016). Widespread RNA binding by chromatin-associated proteins. Genome Biol 17: 28.

6. Love, M. I., Huber, W. and Anders, S. (2014). Moderated estimation of fold change and dispersion for RNA-seq data with DESeq2. Genome Biol 15(12): 550.

7. Majumder, M. and Palanisamy, V. (2021). Compendium of Methods to Uncover RNA-Protein Interactions In Vivo. Methods Protoc 4(1): 22.

8. Ramanathan, M., Porter, D. F. and Khavari, P. A. (2019). Methods to study RNA-protein interactions. Nat Methods 16(3): 225-234. 